\title{
CONSUMER'S EMOTIONAL INFLUENCE \& VISUAL MERCHANDISING EFFECTS: SHOPPING MALLS
}

*PhD Ranjan Upadhyaya \&** MSc Govind Nath Srivastava, India

\begin{abstract}
The research empirically examines the impact of emotional influence in evaluation and purchase decision with special reference to goods sold in shopping malls. Various factors which influence the consumer decision, such as ease offered by retailer to customers in defining, selecting and purchasing the product, brand value, utility of the product, reference group, value for money, advertising and its appeal etc are being critically analyzed and its impact is being empirically assessed. Apart from all the factors, emotion play a critical role in consumer decisionmaking and it strongly influence the consumer's choices. Very little efforts have been done in the past in order to understand the source of emotional arousal in purchase decision. Emotions are subject to change and it is subjective in nature. Emotions silently and unconsciously drive the consumer's decision at the destiny, where customers intend to go. Emotions are not necessarily permanent and it varies from customer to customer and even for the same customer, it is different, in different situation, so in order to be successful in this hyper competitive business era, organizations need to leverage emotions for business success, for better brand value, customer satisfaction and employee management
\end{abstract}

Key words- Emotional dynamics, Neuromarketing, visual merchandising, Mannequins, Emotion Driver.

\section{Introduction}

What \& why customer buy is most important aspect of consumer behavior? What customers buy is well known facts and data are available regarding consumption pattern and frequency of the purchase. Why customer buys is most difficult question of marketing, this must be answered for diagnosis of influences, and for incorporating these influences in marketing mix strategy. The rational decision making, which is being based on price benefit relationship and involves intensive information search have very strong logical and sound justification behind the purchase decision, but unfortunately the consumer's decision which is driven by emotions, do not have such sort of explanation, because emotional attributes are highly qualitative in nature. Emotions guide to specific judgment (Barrett and Campos- 1987). Emotions can guide and persuade consumers (Andrade and Cohen2007).The emotions are all those feelings that so change men as to affect their judgments, and that are also attended by pain or pleasure (Aristotle-2004). Due to qualitative aspects of emotions most of the retailers are not able to incorporate emotional strategy in their marketing strategy. Emotions matters and emotional connect with the customers delivers very strong edge to the firm over traditional, rational appeal. Most of the customers hide their true desire and emotion and that's why their decisions are unconsciously driven by unspoken desire and emotions. The customers, who are relatively more driven by emotion, skip some of the important steps of consumer decision making process and takes decision in shortest span of the time. This increases inventory turnover, return on asset, and quick return on investment and reduces inventory-carrying cost. It is no longer enough to explain to customers what a product can do for him, infact firm need to win the emotion of the customer in order to go deep inside in the heart and mind of the new generation customers (emotion mics, Dann Hills). Consumer decision-making also depends on mood of consumers. Several studies have shown that in a happy mood customers are more driven by their first feeling and emotion and they take quick intuitive judgment. Intuitive decision-making is characterized by sense by which customers perceive an option better than another. The customers are not necessarily able to find out the source of this intuition. Sad individuals are strongly persuaded by strong arguments, but not by weak arguments, whereas happy individuals are moderately persuaded by strong as well as week arguments (Marieke D Vries, Rob W. Holand and Cilia L.M. Witte man, Psychology press). Bolte, Goschke and 
Kuhl, 2003 suggested that happy mood individuals respond more intuitively than those in bad mood. While choosing an option from various alternatives customers may rely on their intuition or customer may decide deliberately by analyzing pros and cons of different option before making final decision. In the world of retailing today almost all the firms are offering the same benefit and more than hundred brands are available in one product category so rational approach of selling the product and product customization will no longer deliver benefit to the firm. Retail firms need to leverage the emotions for grabbing business opportunity. As most of the customer are not able to define the product while purchasing the product and they do not know exactly what they are looking for in terms of colour, feature and benefit so firm should integrate emotions with their merchandising and visual display for acquiring competitive edge over competitors. It is also observed that women are relatively more driven by emotional influence. Colour, status of the person who wear a particular dress in a party or social event, window display, dress style of mannequin with related items, fresh arrivals and new fashion merchandise which is displayed through fixture and attractive visual aids are account for emotional arousal which ultimately drive the purchase decision of customers. It is being observed in the past that Actress of some famous serials created a huge demand for particular dress style and customers blindly purchased the product without any assessment regarding usage, quality and price of the merchandise. In order to succeed in market place retailer should align his merchandising strategy with emotional strategy for catering unspoken desire/ emotion of the customers.

\section{Visual Merchandising as an Emotion Driver}

Visual merchandising is the display tools that transform shoppers into stoppers and passers into buyers. It should be noted that visual merchandising does not impose any idea over customers and works as an idea person and lead the emotion in the direction where customers wish to go. As it is believed that $80 \%$ of influence/impression is created by sight that's why mannequin and window display is weightier than thousands of the words. The impression of different elements of visual merchandising such as colour, light, merchandise, odour, sound is different for different customers as impact of this encounter is unique for each customer in terms of emotional influence.

\section{Elements of Visual Merchandising- Window Display}

Window display is like a visiting card of the store and it is most controllable element of the store in relation to image building. Well-designed window display works like a talking point and communicate with the customers silently regarding merchandise story. Attractive window displays not only draw the attention of the customers and creates first impression but it also entertain pedestrians.

Real setting, Atmospheric setting, Semi real setting, Abstract setting and whimsical setting of window display creates different impact over customer's mind.

\section{Colour}

Medical science has proven that colours have definite and various impact over the nervous system. Colour can immediately create the mood and it is biggest motivation for shopping. Colours cheer us up whenever we feel bad. Colours are associated with human emotions and it is highly individualistic. The problem for the visual merchandiser is that each person may have distinct reaction to the same colour. In the vast and global market place there are cultural and regional differences in colour preference. Following are the general feeling of particular colour.

a) Yellow-caution, cowardice, treachery

b) Red- passion, love

c) Orange- knowledge, warmth, energy, force

d) Violet- royalty, depression

e) Blue- fidelity, sobriety, fear 
f) Green- Wealth, outdoors, luck, nature

g) Brown- Maturity, humility

h) White- Purity, truth

i) Black- Death, sorrow, depression

Sources- (Swati Bhalla, Anurag S, Visual merchandising)

\section{Neuromarketing}

Neuromarketing is emerging field that utilizes medical technologies such as FMRI (functional magnetic Resonance Imaging) and EEG (Electroencephalography) to study the brain's response to marketing stimuli (P Raj Devasagayam, Tara Maloney, DIAS Technology review, vol-6, No-2, Oct-Nov2010). FMRI is used by researcher for measuring the change in the activity of the brain and to learn what part of the brain is affecting decision and why consumers take decision. As it is believed that brand choice of the customers is based on sub conscious thought process so Neuromarketing uses traditional Neuroscientific method to map the brain pattern against encounter between stimuli and brain. It also analyzes impact of these stimuli on consumer decision-making. The Retailer need to do the research at sub conscious level to know what customers are thinking and why and neuromarketing is believed to give answer of these questions. As the participants is shown a particular stimulus, his or her brain is monitored with neuroimaging monitor such as FMRI, EEG, PET, TMS, SCR Etc, . Any one of these monitors can be used for brain mapping. Eventually the brain pattern is interpreted by determining whether or not person liked what he was experiencing and up to what degree.

\section{Views from the field of Neuroscience}

1-“"The essential difference between emotion and reason is that emotion leads to an action while reason leads to conclusion" (Calne, 2000)

2-"Over $85 \%$ of the thought, emotions and learning occur in unconscious mind and it can be said that

\section{reasoning strategies are defective (Damasio, 1999)}

3-"The wiring of the brain favors emotions" (Ledoux, 1996)

(Sources- Advertising journal of Research, March, 2009, John Pawle and Peter Cooper)

\section{Objectives Of the study}

1- $\quad$ To analyze the impact of emotional influence in consumer decision-making.

2- To identify the most important influence in consumer decision making

3- $\quad$ To judge the rationality of consumer decision-making and to find out variation for the same product category.

\section{Literature Review}

John Pawle and Peter Cooper used the Lovemak grid and incorporated quantative as well as qualitative insight for measuring emotions. In their study they found that actual contribution of emotional factors to the brand decision-making is significantly greater than functional factors and ranges from 63-85 $\%$ depending on product category. According to John Pawle and Peter Cooper Human behavior is is heavily influenced by emotions not solely by reason. Consumers are highly emotional and intuitive in their behavior, operating through emotional center of the brain directed by their heart and often independent of conscious control (John Pawle and Peter Cooper). Robert (2004) developed a love mark grid in order to understand the relationship between brand and consumer. In his study he emphasized that brand not only need to create respect but it should also earn respect from customers. Heath-2001 argues that brand decision is not wholly rational. Consumers take the decision via senses, emotions, instinct and intuition. He pointed out that customers are physically incapable of making decision based on purely rational thinking. Kelvin Roberts in his study argued that human beings are powered by emotion and whenever there is conflict between emotion and reason emotion always wins. Myeong -GU-SEO and Feldman Barrett analysed the impact of feeling (good or bad) 
over the decision-making performance. They argued that decision making performance depends on how people experience, treat and use their feeling during decision making and both functional and dysfunctional effects can be simultaneously managed to maximize their positive effects and minimize negative effects. They suggested that affective feeling can improve decision-making performance by facilitating and even enabling decision making process. Damasio (1994) pointed out that feeling boost the conscious attention and continued working memory required for any reasoning or deciding pleasant and unpleasant feelings can help decision makers to resolve this dilemma by invoking distinguishable frame of the mind. Blair Kidwell, David M. Hardesty \& Terry L. Childers argue that EI and emotional processing play a crucial role in highest quality of decision and emotional processing have very strong influence on consumer outcome. Jennifer S. Lerner (Howard University), Seunghee Han and Dacher Keltner Described the significance of incidental emotion as well as integral emotion. They defined the integral emotion as a feeling that is related to judgment or decision at hand. Marieke D. Vries, Rob W. Holand, and Cilia L.M. Witte man in their study argue that compatibility between mood and decision strategy has very strong influence over subjective value of decision outcome. They Examined mood and intuitive Vs deliberative decision-making. In their study they mentioned that Deliberative decision-making is cognition based, precise and slow. Deliberative decision makers take their time to thoroughly analyze the positive and negative aspects of different options.

Luisa Andreu, Enriquebigne, Ruben Chumpitaz and Valerie Swaen investigated the impact of retail environment in two different retail setting (shopping center and traditional retail area. They established the linkage between retail environment, emotion, satisfaction level and behavioral intention of consumers. They formed three-dimensional construct for analyzing behavioral intention. Baron et al described the concept of Retail Theater for creating pleasant experience for increasing satisfaction level and loyalty among consumers. Wakefield and Baker (1998) found that physical environment play a very crucial role in determining consumer's desire to remain at shopping area. The way consumer experience emotion determines his behavioral intention (Yach and Spangenberg2000). It is pointed out that Positive emotion creates approach behavior while negative emotion produces avoidance behavior. Mooy and Roben-2002 in their study found that customer wish to touch the product for better evaluation and purchase decision. On the other hand Argo, Dahl and Morales-2006 demonstrated that customers do not want the product to be touched by the others that they would like to purchase and view touched product as a negatively contaminated. Jenifer J Argo, Darren W. Dahl and Andrea C. Morales examined that when physical contact between the product and another person creates positive outcome for consumers and how consumers respond when other people of varying level of attractiveness touch the product that they wish to purchase.. They brought new insight regarding impact of attractive social influence in consumer decision-making and mentioned that a highly attractive contact source and received consumer must be of opposite sex for positive contagion to occur. Male consumers are more influenced by attractiveness level of another woman and that female consumers are more influenced by attractiveness level of another man (Abbey1982, Buss 1989). Learner and Keltner $(2000,2001)$ used appraisal tendency Framework (ATF) as a basis for describing the effect of specific emotions on judgment and decision making. Ingrid Smithey, Fulmer and Bruce Barry identified neural system for incorporating integral emotions and controlling incidental emotions.

\section{Hypothesis}

a) H1- Consumers primarily take emotional decision driven by emotion

b) H2- Consumers spend less time in Intuitive decision driven by emotions.

c) H3- Consumers feels joy and satisfaction in post transaction driven by emotion. 
Research Design

A structured undisguised questionnaire is used and sample sizes of 200 were taken for study. Both male and female respondents were taken in order to minimize the impact of gender bias. Data are analyzed through SPSS. In the study dependent and independent variables were identified. Consumer's judgment and purchase evaluation is dependent variable while social influence (Attractiveness of contact person), compassion, atmospheric, retail setting, temperature, music, colors, odor, décor, window dishplay, anger, fear, pride, affection etc is independent variable. Respondents were asked to assess their feelings on five point likert scale in order to find out that when customers felt joy, anger, fear, contentment and disgust.

\section{Scope of Research}

This research empirically analyzes the impact of emotional influence in consumer decision making for goods in different retail setting. This study can be further extended for variety of the goods and most importantly the sources of emotional arousal for each product category can be identified. As in a retail setting different factors such as decor, light, color, odour, music, contact person, window display are accountable for emotion formation among the consumers so an effective emotion matrix can be developed in order to incorporate this matrix in sensory marketing.

\section{Analysis and Discussion}

Total 200 questionnaires were distributed among the customers in a different retail setting as each shopping mall have different architectural design, lay out and window display. Finally 175 questionnaires were found usable. Apart from SPSS analysis tool, pie chart is also used to analyze the data. Total 16 questions were asked to respondent to analyze the impact of senses, emotional influence over customer decision making. Majority of the customers admitted that they are strongly driven by their senses in purchase decision and sight is most important influence which energies customers to purchase the goods. Most of the respondent said that they give priority to first impression in purchase decision. We also felt in the research that fragrance, music, light is very important source of emotional arousal and it influence consumer decision making up to great extent. It was also found that most of the customers take intuitive judgment.

\section{Limitation of the Study}

This study is heavily depends on analysis of feelings of just 175 respondents in retail setting. As emotion is very subjective in nature and most of the customers may not be able to express their feelings exactly so the result may not be absolutely accurate. Lastly this study can not be generalized as study is conducted in NCR region only and emotion driver, drive the emotions of consumers based on geographical location. 


\section{Interpretation of the data}

Table-1

How strong you are driven by your senses in purchase decision?

\begin{tabular}{llllll}
\hline \multirow{2}{*}{ Particulars } & \multicolumn{2}{l}{ Frequ } & & \\
& ency & Percent & Valid Percent & Cumulative Percent \\
\hline \multirow{3}{*}{ Valid } & Strongly driven & 94 & 47.0 & 47.0 & 47.0 \\
\cline { 2 - 6 } & Rarely & 52 & 26.0 & 26.0 & 73.0 \\
\cline { 2 - 6 } & Moderately & 52 & 26.0 & 26.0 & 99.0 \\
\cline { 2 - 6 } & Not at all & 2 & 1.0 & 1.0 & 100.0 \\
\cline { 2 - 5 } & Total & 200 & 100.0 & 100.0 & \\
\hline
\end{tabular}

Table-2

Which of five senses hold you most during purchase?

\begin{tabular}{|c|c|c|c|c|c|}
\hline & $\begin{array}{l}\text { Partic } \\
\text { ulars }\end{array}$ & Frequency & Percent & Valid Percent & Cumulative Percent \\
\hline \multirow[t]{6}{*}{ Valid } & See & 118 & 59.0 & 59.0 & 59.0 \\
\hline & Smell & 10 & 5.0 & 5.0 & 64.0 \\
\hline & Touch & 28 & 14.0 & 14.0 & 78.0 \\
\hline & Hear & 14 & 7.0 & 7.0 & 85.0 \\
\hline & Taste & 30 & 15.0 & 15.0 & 100.0 \\
\hline & Total & 200 & 100.0 & 100.0 & \\
\hline
\end{tabular}

Table-3

Do you follow what your senses say during purchasing \& up to what extent?

\begin{tabular}{clllll}
\hline \multicolumn{2}{l}{$\begin{array}{l}\text { Particul } \\
\text { ars }\end{array}$} & Frequency & Percent & Valid Percent & Cumulative Percent \\
\hline Valid & Always & 68 & 34.0 & 34.0 & 34.0 \\
\cline { 2 - 5 } & Rarely & 62 & 31.0 & 31.0 & 65.0 \\
\cline { 2 - 5 } $\begin{array}{l}\text { Sometim } \\
\text { es }\end{array}$ & 34.0 & 34.0 & 99.0 \\
\cline { 2 - 5 } & & 1.0 & 1.0 & 100.0 \\
\hline
\end{tabular}


Table-4

How much passionate you are about your favorite colour in purchase decision?

\begin{tabular}{llllll}
\hline \multicolumn{2}{l}{$\begin{array}{l}\text { Particul } \\
\text { ars }\end{array}$} & Frequency & Percent & Valid Percent & Cumulative Percent \\
\hline Valid & $\begin{array}{l}\text { Very } \\
\text { Deeply }\end{array}$ & 72 & 36.0 & 36.0 & 36.0 \\
\cline { 2 - 5 } & $\begin{array}{l}\text { Moderat } \\
\text { ely }\end{array}$ & 102 & 51.0 & 51.0 & 87.0 \\
\cline { 2 - 5 } & & & 12.0 & 12.0 & 99.0 \\
\cline { 2 - 5 } Rarely & 24 & 1.0 & 1.0 & 100.0 \\
\hline
\end{tabular}

Table-5

Are you ready to spend more money to get your favorite colour?

\begin{tabular}{clllll}
\hline \multicolumn{2}{c}{$\begin{array}{l}\text { Partic } \\
\text { ulars }\end{array}$} & Frequency & Percent & Valid Percent & Cumulative Percent \\
\hline \multirow{2}{*}{ Valid } & Yes & 130 & 65.0 & 65.0 & 65.0 \\
\cline { 2 - 6 } & No & 70 & 35.0 & 35.0 & 100.0 \\
\cline { 2 - 5 } & Total & 200 & 100.0 & 100.0 & \\
\hline
\end{tabular}

Table-6

How much passionate you are about your favorite music?

\begin{tabular}{llllll}
\hline Particulars & Frequency & Percent & Valid Percent & Cumulative Percent \\
\hline \multirow{2}{*}{ Valid } & Very Deeply & 96 & 48.0 & 48.0 & 48.0 \\
\cline { 2 - 6 } & Rarely Matters 62 & 31.0 & 31.0 & 79.0 \\
\cline { 2 - 6 } Moderately & 42 & 21.0 & 21.0 & 100.0 \\
\cline { 2 - 6 } & Total & 200 & 100.0 & 100.0 & \\
\hline
\end{tabular}

Table-7

How much you are driven by your favorite fragrance in purchasing cosmetics?

\begin{tabular}{|c|c|c|c|c|c|}
\hline & Particulars & Frequency & Percent & Valid Percent & Cumulative Percent \\
\hline \multirow[t]{5}{*}{ Valid } & Strongly & 80 & 40.0 & 40.0 & 40.0 \\
\hline & Moderately & 74 & 37.0 & 37.0 & 77.0 \\
\hline & Sometimes & 42 & 21.0 & 21.0 & 98.0 \\
\hline & $\begin{array}{l}\text { Not so } \\
\text { effective }\end{array}$ & 4 & 2.0 & 2.0 & 100.0 \\
\hline & Total & 200 & 100.0 & 100.0 & \\
\hline
\end{tabular}




\section{Table-8}

Do you feel that music, and fragrance in the shopping mall energies you for purchasing more?

\begin{tabular}{|c|c|c|c|c|c|}
\hline & Particulars & Frequency & Percent & Valid Percent & Cumulative Percent \\
\hline \multirow[t]{5}{*}{ Valid } & $\begin{array}{l}\text { Strongly } \\
\text { agree }\end{array}$ & 56 & 28.0 & 28.0 & 28.0 \\
\hline & Agree & 106 & 53.0 & 53.0 & 81.0 \\
\hline & Disagree & 32 & 16.0 & 16.0 & 97.0 \\
\hline & Indifferent & 6 & 3.0 & 3.0 & 100.0 \\
\hline & Total & 200 & 100.0 & 100.0 & \\
\hline
\end{tabular}

\section{Table-9}

Do you get more satisfaction when you purchase the goods based on first impression rather than deliberately analyzing the pros and cons of product?

\begin{tabular}{|c|c|c|c|c|c|}
\hline & Particulars & Frequency & Percent & Valid Percent & Cumulative Percent \\
\hline \multirow[t]{5}{*}{ Valid } & Strongly agree & 26 & 13.0 & 13.0 & 13.0 \\
\hline & Agree & 110 & 55.0 & 55.0 & 68.0 \\
\hline & Disagree & 54 & 27.0 & 27.0 & 95.0 \\
\hline & Indifferent & 10 & 5.0 & 5.0 & 100.0 \\
\hline & Total & 200 & 100.0 & 100.0 & \\
\hline
\end{tabular}

Table-10

How strong are you in distinguishing or identifying stimulus, when you are given blindfold?

\begin{tabular}{clllll}
\hline Particulars & Frequency & Percent & Valid Percent & Cumulative Percent \\
\hline Valid & Always & 18 & 9.0 & 9.0 & 9.0 \\
\cline { 2 - 6 } & Most of times & 82 & 41.0 & 41.0 & 50.0 \\
\cline { 2 - 6 } $50-50$ & 82 & 41.0 & 41.0 & 91.0 \\
\cline { 2 - 5 } Rarely & 18 & 9.0 & 9.0 & 100.0 \\
\hline Total & 200 & 100.0 & 100.0 & \\
\hline
\end{tabular}

\section{Table-11}

Are you so strongly driven by your senses that you overlook your budget?

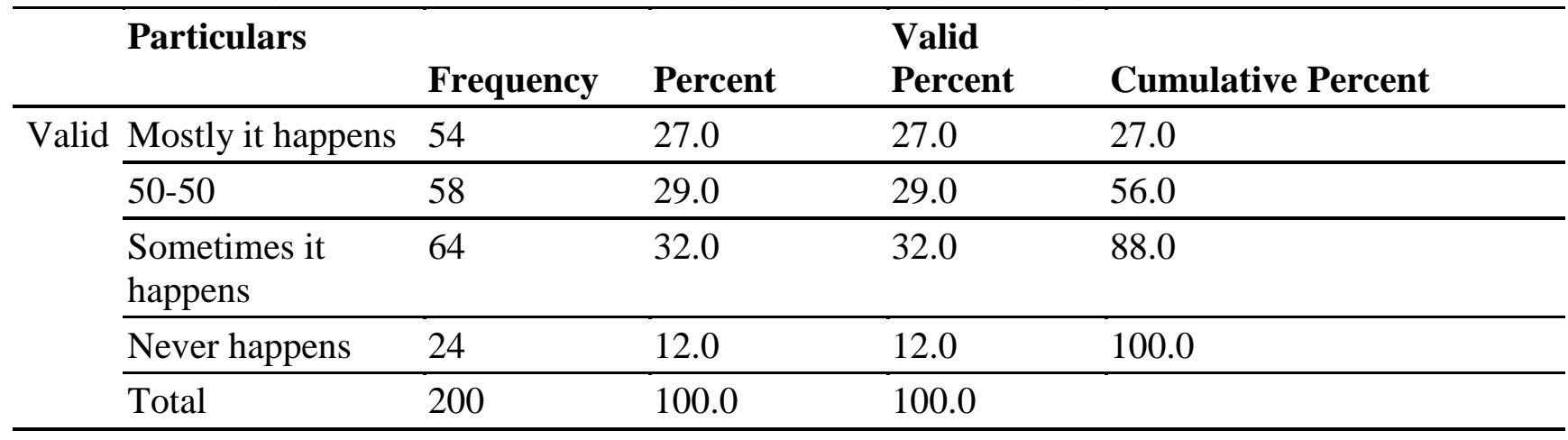


Table-12

Do you go for analysis of price benefits when you find it as priority of your taste?

\begin{tabular}{llllll}
\hline Particulars & Frequency & Percent & Valid Percent & Cumulative Percent \\
\hline \multirow{2}{*}{ Valid } & Always & 58 & 29.0 & 29.0 & 29.0 \\
\cline { 2 - 6 } & $50-50$ & 98 & 49.0 & 49.0 & 78.0 \\
\cline { 2 - 6 } & Rarely & 36 & 18.0 & 18.0 & 96.0 \\
\cline { 2 - 5 } Never & 8 & 4.0 & 4.0 & 100.0 \\
\cline { 2 - 5 } & Total & 200 & 100.0 & 100.0 & \\
\hline
\end{tabular}

Table-13

How many times conflict takes between emotions \& reasons in purchase decision?

\begin{tabular}{llllll}
\hline & Particulars & Frequency & Percent & Valid Percent & Cumulative Percent \\
\hline \multirow{2}{*}{ Valid } & Always & 22 & 11.0 & 11.0 & 11.0 \\
\cline { 2 - 6 } & Sometimes & 130 & 65.0 & 65.0 & 76.0 \\
\cline { 2 - 6 } & Rarely & 40 & 20.0 & 20.0 & 96.0 \\
\cline { 2 - 6 } & Never & 8 & 4.0 & 4.0 & 100.0 \\
\cline { 2 - 5 } & Total & 200 & 100.0 & 100.0 & \\
\hline
\end{tabular}

Table-14

How much time you take to make purchase decision when you are emotionally driven?

\begin{tabular}{llllll}
\hline \multicolumn{2}{c}{ Particulars } & Frequency & Percent & $\begin{array}{l}\text { Valid } \\
\text { Percent }\end{array}$ & Cumulative Percent \\
\hline \multirow{2}{*}{ Valid } & Spontaneously & 46 & 23.0 & 23.0 & 23.0 \\
\cline { 2 - 5 } & $\begin{array}{l}\text { Discuss and consult with } \\
\text { friends }\end{array}$ & 96 & 48.0 & 48.0 & 71.0 \\
\cline { 2 - 5 } & & & & 96.0 \\
\cline { 2 - 6 } & Think of pros and cons & 50 & 25.0 & 25.0 & 100.0 \\
\cline { 2 - 6 } & Try to contect user/users & 8 & 4.0 & 4.0 & \\
\hline
\end{tabular}

Table-15

How emotional influence is important for you and it affect your purchase decision?

\begin{tabular}{clllll}
\hline \multirow{2}{*}{ Valid } & Particulars & Frequency & Percent & Valid Percent & Cumulative Percent \\
\cline { 2 - 6 } & Very important & 36 & 18.0 & 18.0 & 18.0 \\
\cline { 2 - 6 } & Moderately important & 110 & 55.0 & 55.0 & 73.0 \\
\cline { 2 - 6 } & Not important & 38 & 19.0 & 19.0 & 92.0 \\
\cline { 2 - 6 } & Indifferent & 16 & 8.0 & 8.0 & 100.0 \\
\cline { 2 - 6 } & \multicolumn{2}{c}{ Total } & & 100.0 & 100.0 \\
\hline
\end{tabular}


Table-16

Do you give priority to emotion over reason during the purchase decision?

\begin{tabular}{llllll}
\hline \multirow{2}{*}{ Valid } & Frequency & Percent & $\begin{array}{l}\text { Valid } \\
\text { Percent }\end{array}$ & Cumulative Percent \\
\hline \multirow{1}{*}{} & Always & 18 & 9.0 & 9.0 & 9.0 \\
\cline { 2 - 6 } & Sometimes & 104 & 52.0 & 52.0 & 61.0 \\
\cline { 2 - 6 } & Rarely & 24 & 12.0 & 12.0 & 73.0 \\
\cline { 2 - 6 } & Never & 16 & 8.0 & 8.0 & 81.0 \\
\cline { 2 - 6 } & $\begin{array}{l}\text { Both emotion and reason } \\
\text { are equally important }\end{array}$ & 38 & 19.0 & 19.0 & 100.0 \\
\cline { 2 - 6 } & Total & 200 & 100.0 & 100.0 & \\
\hline
\end{tabular}

\section{Conclusion}

Most of the customers hear to their emotion while taking decision that's why their decision is primarily driven by the emotion and emotional influence play a very important role in consumer decision making process. It is also found from the research that intuitive decision driven by the emotion provide more post purchase satisfaction and pleasure .It is also found during the study that emotion based decision take less time in purchase decision as compared to reason based decision making.

\section{Reference}

1) John Pawle and Peter Cooper 'Measuring Emotion-Love marks, the future beyond brands', Journal of advertising Research-March-2006,

2) Lisa Feldman Barrett 'Being emotional during decision making good or bad? An empirical investigation', Academy of management journal, 2007, volume-50,

3) Blair Kidwell, David M. Hardestyand Terry L.Childers 'consumer emotional intelligence', Advances in consumer research, vol-35, 2008

4) Lennifer S. Lerner, Seunghee Han and Dacher Keltner 'Feelings and consumer decision making-Extending the appraisal tendency framework', Journal of consumer psychology
5) Marieke Dvries, Rob W. Holand and Cilia L. M. Witteman 'Fitting decisions: Mood and intuitive deliberative decision strategy', Psychology press

6) Jennifer J. Argo, Darren W. Dahl and Andrea C.Morales 'Positive consumer contagion: Responses to attractive others in a retail context', Journal of marketing research, vol-xlv, dec-2008, pp-690-701

7) Ingrid Smithey Fulmer and Bruce Barry 'Managed hearts and Wallets: Ethical issues in emotional influence by and within the organisation', Business ethics quarterly 19.2, April-2009 